\title{
2015 Annual Report of China Southern Airlines Co., Ltd. Yuyu Cao ${ }^{1, a}$ \\ ${ }^{1}$ Shandong University, Weihai city, Shandong Province, 264209, China a2726783695@qq.com
}

Keywords: China southern airlines; Financial analysis; Corporate valuation

\begin{abstract}
This paper researches the annual financial report of China Southern Airlines(hereinafter referred to as "Southern Airlines", stock code: 600029) from 2011 to 2015. To be concluded, the short-term debt-paying ability of China Southern Airlines is poor, the long-term solvency is at the industry average level, the operating capacity is higher than the industry average level, the profitability is lower than the industry average level and the development ability is good. Last but not the least, I put forward reasonable proposals for China Southern Airlines to help it realize its further development.
\end{abstract}

\section{Company Profile}

China Southern Airlines co., LTD. (China Southern Airlines, referred to as "Southern" or "China Southern Airlines"), headquartered in guangzhou, with blue vertical tail with red kapok logo for the company, is China's largest transport aircraft, in the most developed route network, the biggest airline passenger Numbers. China southern airlines fleet ranks first in Asia, fifth in the world, is the world's first run at the same time the airbus A380 and Boeing 787 airlines. Is the largest number of flights, and route network in the most densely populated, passenger's largest civil aviation company .

\section{The Overall Financial Statements Analysis}

Analysis of the Balance Sheet. From the point of the overall size, in 2015, China southern airlines decreased by $70.26 \%$ compared to the monetary funds, mainly is the monetary funds in the bank deposit from 13.6 billion yuan to 2.38 billion yuan (RMB 11.22 billion). Assets decreased by $1.82 \%$ year-on-year. Monetary funds accounted for the proportion of total assets at the beginning of the year, up from $9.65 \%$ down to $2.92 \%$ at the end of the year. In 2015, the currency capital to total assets serious decline, the proportion of relatively few company monetary fund holdings., the safety of the assets are relatively weak, the quality is not good.

The Income Statement Analysis. In addition to decrease slightly in 2013, China southern's revenue in five years presents ascendant trend overall. In 2015, operating income growth of $2.91 \%$ over the previous year, operating income of better quality. From 2011 to 2014, China southern airlines operating profit decline, to reach the lowest 405 million yuan in 2014, operating profit of 2.624 billion yuan in 2015 , operating profit growth of $547.90 \%$ over the previous year, operating profit revenue share rise.

In 2015, China southern's revenue accounted for $96 \%$ of total revenue, non-operating income is $3 \%$, the yield is $1 \%$. Shows the distribution of their income is quite reasonable.

The Cash Flow Statement Analysis. For five years, China southern airlines operating activities net cash flow in general is on the rise, and rise significantly in 2015. In 2015, operating activities net cash flow increased $70.10 \%$ year-on-year, the operating activities cash inflow, a year-on-year increase of 4.682 billion yuan, operating activities cash outflows 5.915 billion yuan less than last 
year, including "purchase of goods and accept payment in cash" services to reduce 9.183 billion yuan over the previous year. Compared with other three airlines industry, you can see that China southern airlines operating activities net cash flow is higher than the industry average, shows that the quality is better.

\section{The Financial Ratio Analysis}

Solvency. From 2011 to 2014, China southern airlines the liquidity ratio in the industry of higher level, debt paying ability is stronger. In 2015 , the current ratio from 0.51 to 0.22 , a year by a sharp decline, suggests that the company's short-term solvency was weakened, in 2015, the short-term debt paying ability, low level in the industry. China southern's liquidity ratio between 0.2 and 0.5 , and that the other three airlines flow rate is less than 0.8 , the flow rate is low, it has to do with the characteristics of the aviation industry.

From 2011 to 2014, quick ratio in the industry of high level, debt paying ability is stronger. In 2015 , the quick ratio from 0.48 to 0.20 , a year by a sharp decline, suggests that the company's short-term solvency was weakened, in 2015 , the short-term debt paying ability, low level in the industry.

2011-2014, the cash ratio of China southern airlines is higher than the industry average, ability to pay slightly higher than the industry average. In 2015 , the cash ratio is low, that ability to pay is low, poor to pay the debt security.

Operating Capacity. Nearly five years, China southern's accounts receivable turnover ratio in the industry of higher level, showed better liquidity of accounts receivable. However, since 2012, the index has been slightly lower, shows that China southern airlines should pay attention to the management of accounts receivable.

Nearly five years, China southern's inventory turnover in the industry average, and more stable, shows that China southern airlines for better inventory management. The flow of the 2011-2014, China southern airlines asset turnover in the industry average, a higher level, the index in 2015 in an industry that liquidity of the company's assets in the industry leading level, China southern airlines better management of the current assets. China southern's fixed asset turnover in the industry at a higher level, indicates that the management of the fixed assets is better than other airlines industry, but still need to further strengthen the management of fixed assets. From 2011 to 2011, China southern airlines, the total asset turnover dropped year by year, the industry of other airlines, the index also is on the decline on the whole, this may be related to the overall development level of economy and industry change. However, China southern's total asset turnover at a higher level in the industry and shows that the management of the total assets is better than other airlines in the industry. Southern of shareholders' equity turnover slightly higher than the industry average, show that the use of its assets to the owner high efficiency, operation ability is slightly higher than that of other airlines in the industry.

Through the above analysis shows that in 2015, China southern's accounts receivable turnover ratio, current asset turnover, fixed asset turnover and total asset turnover and Stockholders' equity turnover rates were higher than the industry average, the average level of inventory turnover in the industry. So, China southern airlines operating ability strong, and higher than the industry average.

Profitability. 2011-2013, China southern airlines total return on assets in the industry average, significantly below the industry average of 2014, 2015, slightly below the industry average. Show that in 2015 China southern airlines use total assets, low efficiency of the poor profitability. In 2015, China southern's return on equity low, generally in an industry that shareholders obtain investment reward is low, enterprise's profit ability is poor. Nearly five years, China southern airlines sales net 
interest rates at low levels in the industry, show that the proposed by increasing sales revenue the ability is poor. In 2015, China southern margin of the cost is lower than the industry average, explain the revenue to pay for the cost is larger, the cost control and management level is poor, poor corporate profitability. In 2011, 2012 and 2015, China southern airlines, the basic earnings per share in the industry average, shows that China southern's outstanding common stock share of profits in the industry average, profitability. 2013 and 2014, China southern's earnings per share is lower than the industry average, poor profitability.

Through the above points, in 2015 , China southern, the total return on assets, return on equity sales net interest rate, cost, profit margins are lower than the industry average, basic earnings per share in the industry average, net assets per share is higher than the industry average. Show that in 2015 China southern poor profitability, lower than the industry average, but profitability stronger gradually, the development trend is good.

The Dupont Analysis. Return on equity $=$ sales net interest rates * average equity multiplier total asset turnover. China southern net assets yield $=10.63 \%$ to $4.47 \%$ of the $2015 * 0.59 * 0.59$, China southern net assets yield $=5.59 \%$ to $2.23 \%$ of the $2014 * 0.61 * 4.11$, and changes in net assets yield of 5.04\%. First of all, analyze the sales net interest rate changes on the influence of the return on equity: according to this year's sales net interest rate of return on equity last year $=0.61 *$ $0.61 * 0.61=4.47 \%$, sales net interest rate changes affect $=11.21 \% 5.59 \%=5.62 \%$. Second, the analysis of the effect of total asset turnover to return on equity: according to this year's sales net interest rate and net assets yield $=4.47 \%$ of the total asset turnover, the previous year $* 0.59 * 4.11$ $=10.84 \%$, the impact of changes in the total asset turnover $==10.84 \%-10.84 \%-0.37 \%$. Again, the analysis of the effect of changes in financial leverage $==10.63 \%-10.63 \%-0.21 \%$. Through the analysis shows that the most advantageous factor is the sales net interest rates rise, the net assets yield increased by $5.62 \%$. The most unfavorable factor in the decline of the total asset turnover net assets yield decreased by $0.37 \%$; Second is a decline in the average equity multiplier, the net assets yield decreased by $0.21 \%$. Advantages more than disadvantages, so the net assets yield increased by $5.04 \%$. So, should focus on the influence of sales net interest rate changes. Therefore, China southern airlines to further strengthen the control of cost, make the future sales net interest rates rising steadily.

\section{Suggestions}

\section{For the Internal Operation Suggestion}

1. To strengthen the management and control of debt, to strengthen the short-term solvency and long-term solvency.

2. To achieve sales revenue increased, to strengthen the control of cost, expenses, etc, to improve the profitability of the enterprise.

3. Maintain and improve the level of the enterprise operation ability and development ability, to find a solution to the sustainable and healthy development.

4. The proper use of financial leverage and operating leverage, financial risk and business risk control in the proper level.

\section{In View of the External Environment}

1. Pay attention to the macro environment risk. First of all, pay attention to the macroeconomic volatility risk. Cycle of civil aviation transportation industry is closely related to the domestic and international macroeconomic development, macro economic prosperity degree directly affect the development of the economic activity, the residents' disposable income and import and export trade volume increase or decrease, thus affecting the air passenger and freight demand, influence business 
performance. Second, pay attention to the macroscopic policy risk. Macroeconomic policies by the government, especially the periodic macroeconomic policies such as credit, interest rate, exchange rate, fiscal expenditure, etc., will make the air transportation industry, directly or indirectly affected. In addition, the government is open to the establishment of airlines, navigation, routes and ticket prices have been regulated, and also stipulates that the fuel pricing mechanism. Any change of policy may also affect the company's operating results and the development of future business.

2. Pay attention to the industry risk. First of all, pay attention to the risk of industry competition. Domestic civil aviation transportation industry market gradually opening, four major airlines and foreign airlines and small and medium-sized airlines in terms of scale, flight, price, service competition, the company's business model and management level of the larger challenge. Second, to pay attention to the competition risk of other modes of transportation. Air transportation, railway transportation and road transportation in ZhongDuanTu transportation alternative. With the expansion of the emu, a national high-speed rail network of construction and the improvement of the highway network between cities, these alternative to the development of China southern air transport business has formed a certain competitive pressure. Again, pay attention to the force majeure and other unpredictable risks. Airlines are greatly influenced by the external environment, natural disasters such as earthquake, typhoon, tsunami, sudden public health events and terrorist attacks will affect the normal operations of the airlines.

3. Pay attention to security risks. Flight safety is the premise and foundation of airlines to normal operations. Bad weather, mechanical failure, human error, such as the plane defects are likely to pose a threat to flight safety. China southern airlines fleet size large. Long distance running, run overnight, international operation is more, the safe operation of the faced a test.

4. Pay attention to financial risk. First of all, pay attention to the exchange rate volatility risk. China southern most of the financing lease liabilities, Banks and other loans and assume all in foreign currency as the unit operating leases, mainly is the dollar, the euro and the yen. Due to the China southern airlines foreign currency debt is generally higher than that of foreign currency assets, so this group depreciation or appreciation of the yuan against the foreign currency will constitute a significant impact on performance. Second, pay attention to the fuel price volatility risk. Jet fuel costs is one of the main airline costs. The international crude oil price fluctuation and the national development and reform commission for the adjustment of the domestic aviation fuel prices, our group's profits have a significant impact.

\section{Enterprise Valuation}

\section{P/E Valuation Method}

Nearly five years four airlines p/e ratio comparison is shown in Fig. 1: 


\section{P/E Ratio Contrast}

\section{- southern airlines - easthern airlines hainan airlines - Chinese national airlines}

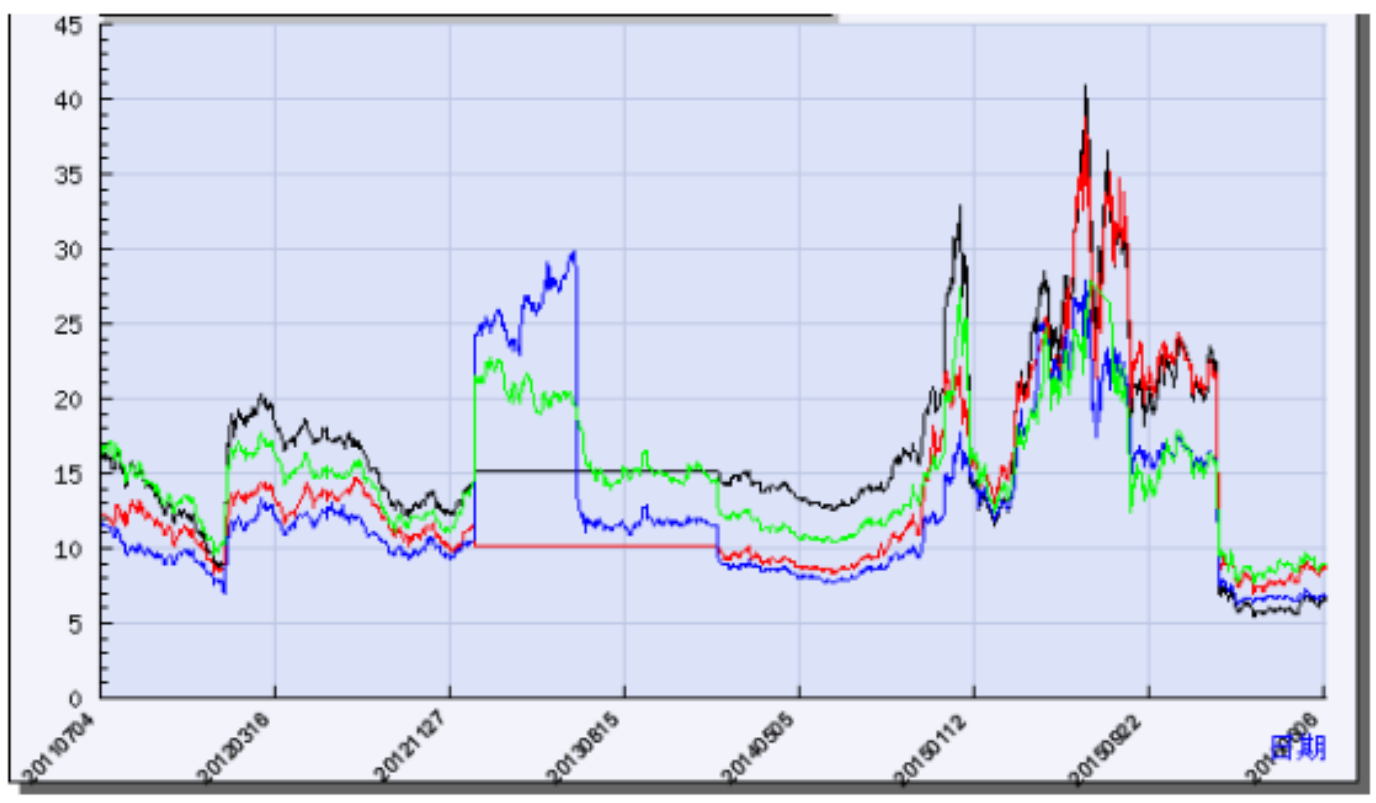

Figure 1. four airlines p/e ratio nearly five years

Can be seen in figure 1, 2011 and 2014, four major airlines p/e ratio remains in a relatively stable level, in 2015, the big four airlines earnings volatility is larger, and compared with the first four years, the overall increase, this is because oil prices falling, and the strong momentum of economic growth, and other positive factors in the airline industry, make the airline to obtain high profits, industry development is good. As of December 31, 2015, China southern's p/e ratio at higher levels in the industry, after China southern's p/e ratio at a lower level in the industry. Through the financial analysis of China southern airlines and its financial comparative analysis with other three airlines, China southern airlines in 2015 financial condition is good, but since 2016, China southern's p/e ratio in the industry at low levels, shows that the market value of China southern airlines to be underestimated. Therefore, China southern's investment value is larger.

Price-To-Book Valuation Method

Nearly five years four airlines price-to-book comparison is shown in fig. 2: 


\section{P/B Ratio Contrast}

\section{- southern airlines - easthern airlines hainan airlines - Chinese national airlines}

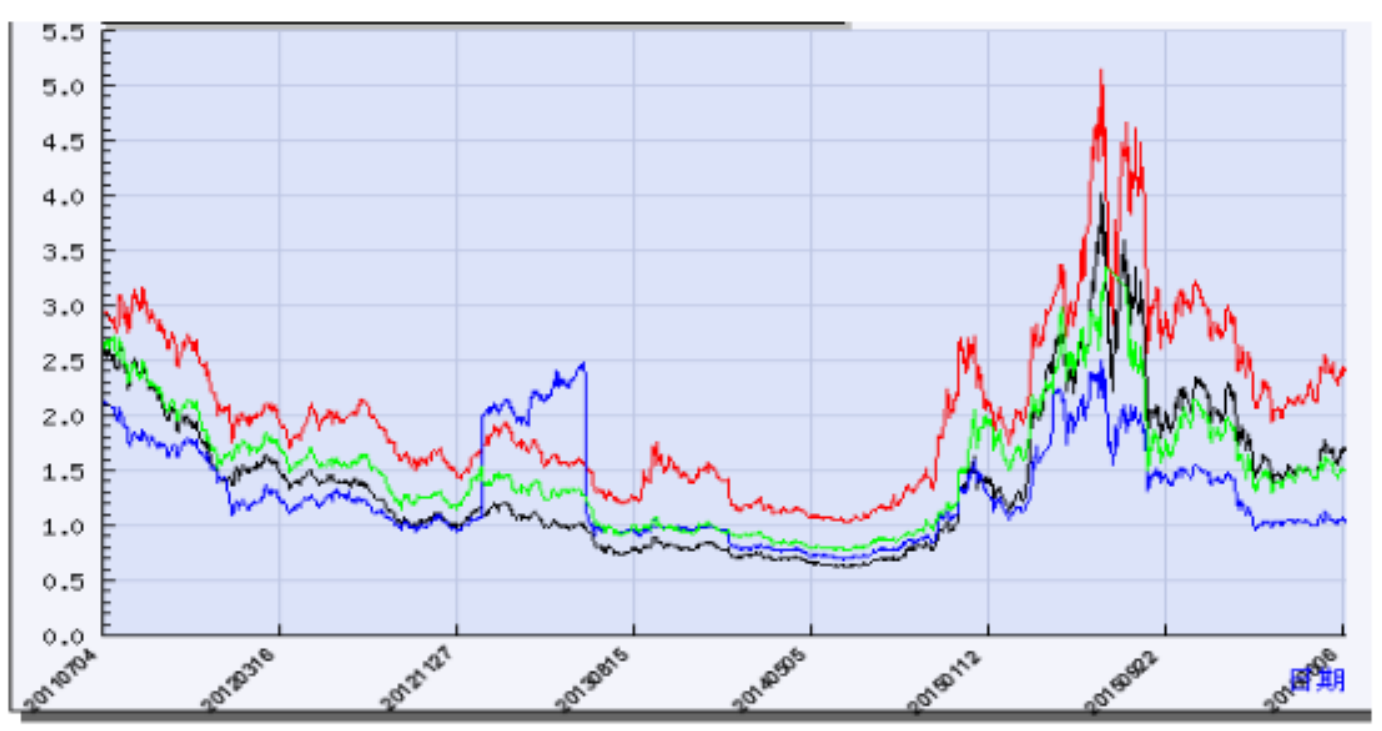

Figure 2. in nearly five years in four major airlines price-to-book contrast

The fig. 2 shows that from 2011 to 2014, the big four airlines price-to-book appear slightly downward trend on the whole, this to the overall development level of the industry. In 2015, the city net rate of volatile and improved than in the previous four years, it shows that in 2015 four airlines operate performance improved. Similar change trend of price-to-book ratio and p/e ratio, this may be related to such factors as the industry factors and market environment. By contrast, can be found from 2012 to 2014, China southern's price-to-book ratio in the industry generally low, high level since 2015, on the whole, in an industry, show that in the future, may have bigger promotion, market of China southern airlines gives high price-to-book, that market to the company's growth prospects look good. So from the analysis of the change trend of the price-to-book, China southern's investment value is bigger.

the Discount Cash Flow Method. Discounted cash flow technique is future cash flow of the enterprise and its expected risk, and then select the reasonable discount rate, and will be converted into present value of future cash flow. Discount cash flow model for:

corporation value $=\sum_{t=1}^{n} \frac{C F t}{(1+r)^{t}}$

$\mathrm{N}$ for the assets of fixed number of year

$\mathrm{CFt}$ is the cash flow for $\mathrm{t}$ years

$\mathrm{R}$ to include the expected cash flow risk discount rate

China southern's cash flow forecast as shown in table 1: 


\begin{tabular}{|l|l|l|l|l|l|}
\hline \multicolumn{2}{|l|}{ Table 1 China southern cash flow forecast } & \multicolumn{4}{l|}{ Units: one million yuan } \\
\hline Project/year & $\mathbf{2 0 1 1}$ & $\mathbf{2 0 1 2}$ & $\mathbf{2 0 1 3}$ & $\mathbf{2 0 1 4}$ & $\mathbf{2 0 1 5}$ \\
\hline Net Profit & 6049 & 3795 & 2649 & 2418 & 4986 \\
\hline $\begin{array}{l}\text { Net profit } \\
\text { growth rate }\end{array}$ & $-5.85 \%$ & $-37.26 \%$ & $-30.20 \%$ & $-8.72 \%$ & $106.20 \%$ \\
\hline Project/year & $\mathbf{2 0 1 6}$ & $\mathbf{2 0 1 7}$ & $\mathbf{2 0 1 8}$ & $\mathbf{2 0 1 9}$ & $\mathbf{2 0 2 0}$ \\
\hline $\begin{array}{l}\text { Cash flow } \\
\text { forecast }\end{array}$ & 5311.59 & 5658.43 & 6027.93 & 6421.55 & 6840.88 \\
\hline $\begin{array}{l}\text { Discount } \\
\text { factor }\end{array}$ & 1.08 & 1.17 & 1.26 & 1.36 & 1.47 \\
\hline $\begin{array}{l}\text { Discounted } \\
\text { cash flow }\end{array}$ & 4918.14 & 4851.19 & 4785.17 & 4721.73 & 4657.46 \\
\hline
\end{tabular}

The first step: the cash flow forecast from 2016 to 2020

Using the discount cash flow model, and in 2011 to 2015, net profit and its quality analysis, can be calculated from 2016 to 2020, the annual cash flow. First, assume that the company's net profit is the cash flow of the year. Due to the China southern airlines nearly five years of volatile, net profit growth is not very stable, together with its position in the industry is slightly higher than the industry average, therefore, can be used in 2015, Air China, China Eastern airlines and hainan airlines of the average net profit growth for predict the parameters of the China southern net profit in 2016. In 2015, Air China, China Eastern airlines and hainan airlines net profit growth rate of $6.22 \%, 4.84 \%$ and $8.52 \%$ respectively, take the average of the three average net profit growth rate can be obtained for $(6.22 \%+4.84 \%,+8.52 \%) / 3=6.53 \%$. Therefore, China southern 2016 cash flow can be predicted for $4986 \times(1+6.53 \%)=5311.59$ (one million yuan), which can predict the cash flow from 2017 to 2020.

Step 2: the discount of cash flow

Assume the discount rate is $r=8 \%$, can be calculated from 2016 to 2020, discounted cash flow.

In 2016, China southern airlines discount cash flow for the CF $(2016) /(1+8 \%)=5311.59 /(1+$ $8 \%)=4918.14$, in the same way to calculate the discount cash flow of the rest of the year.

From 2016 to 2020, the total amount of the discount cash flow was 23933.69 (one million yuan) $=$ one million yuan.

Step 3: perpetual annuity present value calculation

Assume that a sustainable pension for $\mathrm{g}=3 \%$ growth. Perpetual annuity present value $=[\mathrm{FCF}$ $(2020) \times(1+\mathrm{g}) /(\mathrm{rg})] /(1+\mathrm{r}) 5$

Therefore, you can come to perpetual annuity present value is $4657.46 \times 1.03$ present 0.05 present $(1+8 \%), 5=\$ 65.2678$ billion $=\$ 65267806800$.

Step 4: the owner's equity in total

Total owners' equity $=23933690000+65267806800=23933690000$ yuan.

Step 5: calculate price

As of December 31, 2015, the total equity for the China southern airlines is 9817567000 shares. The value per share is 89200496800 present $9817567000=9.09$ yuan/share.

Calculated the price of 9.09 yuan per share, and China southern's actual stock price of 7.10 yuan. Stock valuation is greater than the actual price, so the market value of the China southern airlines is undervalued.

\section{Summary}

By p/e valuation method, price-to-book valuation method and discounted cash flow valuation 
method, you can see that China southern airlines has good market prospects, China southern's investment value is bigger, can consider to buy the shares of China southern airlines. And, in the next few years China southern's enterprise value will have certain amplitude increase, can consider to increase its stake in stock, in order to obtain the corresponding benefits.

\section{Reference}

[1] baidu. Baidu encyclopedia [EB/OL]. [2016]. http://baike.baidu.com/link? Url = 9 vajihjfqlukklwnzvggzelnvbaqkpsjnx4ler6x4uec7rlvmi_trrxvvihu4fgua3ukpsc7vdi8zirbzpq a9f

[2] China southern airlines. Company profile [EB/OL]. [2016]. http://www.csair.cn/cn/pages/ Company. Aspx

[3] China southern airlines, China southern airlines co., LTD. 2015 annual report [R]. Guangzhou: China southern airlines co., LTD., 2016:63-64.

[4] business in shenzhen big data co., LTD. 2014-2018, the industry development of special study [R]. Shenzhen: shenzhen big data in the business information co., LTD., 2014.

[5] China southern airlines, China southern airlines co., LTD. 2015 annual report [R]. Guangzhou: China southern airlines co., LTD., 2016:125-126.

[6] China southern airlines, China southern airlines co., LTD. 2015 annual report [R]. Guangzhou: China southern airlines co., LTD., 2016:139.

[7] China southern airlines, China southern airlines co., LTD. 2012 annual report [R]. Guangzhou: China southern airlines co., LTD., 2013:71.

[8] China southern airlines, China southern airlines co., LTD. 2014 annual report [R]. Guangzhou: China southern airlines co., LTD., 2015:98.

[9] Stephen a. Ross, Randolph w. west field, Jeffrey f. jefferies. Corporate finance [M]. Shinong wu, yifeng shen, wang zhiqiang. Beijing: mechanical industry press, 2011:36 37.

[10] the Chinese institute of certified public accountants, financial cost management [M]. Beijing: China financial economic publishing house, 2015-40

[11] China southern airlines, China southern airlines co., LTD. 2011 annual report [R]. Guangzhou: China southern airlines co., LTD., 2012-60.

[12] China southern airlines, China southern airlines co., LTD. 2013 annual report [R]. Guangzhou: China southern airlines co., LTD., 2014:65.

[13] China southern airlines, China southern airlines co., LTD. 2015 annual report [R]. Guangzhou: China southern airlines co., LTD., 2016:149. 